\title{
Balinese Puppet Style As An Idea Of Ceramic Art Creation
}

\author{
I Wayan Mudra ${ }^{1}$, I Gede Mugi Raharja ${ }^{2}$, I Nyoman Wiwana ${ }^{3}$, I Wayan Sukarya ${ }^{4}$. \\ ${ }^{1}$ Art Craft Study Program, Faculty of Visual Art and Design, Indonesian Institute of the Arts Denpasar, \\ Nusa Indah Street, Denpasar Bali, 80236, Indonesia. \\ ${ }^{2}$ Interior Design Study Program, Faculty of Visual Art and Design, Indonesian Institute of the Arts Denpasar, \\ Nusa Indah Street, Denpasar Bali, 80236, Indonesia. \\ ${ }^{3,4}$ Fine Art Study Program, Faculty of Visual Art and Design, Indonesian Institute of the Arts Denpasar, Nusa \\ Indah Street, Denpasar Bali, 80236, Indonesia.
}

wayanmudra@isi-dps.ac.id

\begin{abstract}
Ceramic art products distributed in Indonesia are dominantly found as Chinese identity. This creation is aimed to create the art ceramics by Balinese style puppet ornaments. The creation method followed Gustami's theory, namely exploration, improvisation, and embodiment. At the exploration stage, the data collection wasconducted through observation, interviews, and documentation. The design process was conducted in the improvisation stage, while the process of forming, burning, and finishing were conducted in the embodiment stage. The partners involved in this creation are UD Tri Surya Keramik and Bali Technology Center of Creative Ceramic Industry (BTIIK). The results of the creation show several works which have been created were inspired by the forms of potteries from Bali, Lombok, and Java which are marketed in Bali, namely sangku (rice bowl) and vase with various ornaments and sizes. This ceramic artwork was made using rotary technique and burned to a temperature of $1250^{\circ} \mathrm{C}$. Balinese puppet style ornaments were applied using painting techniques.
\end{abstract}

Keyword: style, Balinese puppet, creation, ceramic art, ornament

\section{Wayang Bali Sebagai Ide Penciptaan Seni Keramik}

Produk Seni keramik yang dibuat dan dijual di Indonesia dominan ditemukan berindentitas Cina. Tujuan dari penelitian ini adalah untuk menciptakan produk seni keramik berornamen wayang style Bali. Metode penciptaan mengikuti teori Gustami, yaitu eksplorasi, improvisasi, dan perwujudan. Tahap eksplorasi, dilakukan pengumpulan data melalui observasi, wawancara, dan dokumentasi. Tahap improvisasi dilakukan proses desain dan pada tahap perwujudan dilakukan proses pembentukan, pembakaran dan finishing. Mitra yang dilibatkan dalam perwujudan adalah UD Tri Surya Keramik di Desa Kapal, Badung Bali dan Balai Teknologi Industri Kreatif Keramik (BTIKK) Bali. Hasil penciptaan menunjukkan beberapa karya seni keramik tercipta terinspirasi dari bentuk-bentuk gerabah Bali, Lombok, dan Jawa yang dipasarkan di Bali, seperti sangku dan guci. Karya seni keramik ini dibuat dengan teknik putar dan dibakar sampai mencapai suhu $1250^{\circ} \mathrm{C}$. Karya seni keramik yang diciptakan berbentuk sangku dan guci dengan beberapa variasi ornamen dan ukuran. Wayang style Bali menjadi ornamen karya seni keramik ini, dibuat dengan teknik lukis.

Kata kunci : style, Wayang Bali, kreasi, seni keramik, ornamen

Peer review : 9 - 23 Agust 2018, Accepted : 3 September 2018 


\section{INTRODUCTION}

There are no ceramic artworks which are produced in order to showcase the characteristics of Indonesia obtained from the traditional culture such as puppet in Bali or even in Indonesia. That problem becomes the source of intentions to create ceramic artwork. On the contrary, it is very easy to find ceramic art products that feature the characteristics of Chinese culture which are produced by ceramic craftsmen in Indonesia. Indonesia is rich with various traditional cultures that can be potentially developed in creative industries such as ceramic art. Ceramic art activists should be able to explore traditional cultures such as puppet to develop their products so that the works that have been created represent the characteristics of Indonesia. Whether or not the products are received by consumers will be determined by the quality of the product.

In the preliminary survey, we found the marketing of Chinese-style ceramic products which are characterized by the decoration of dragon motifs seen marketed in various places in Bali such as in several shops on Jalan Gajah Mada Denpasar. Likewise, Chinese-style ceramics are seen being sold at the "Sumber Rejeki" art shop on Sukawati Highway No.66, Banjar Tabuana Gianyar. The ceramic products are imported from outside Bali.

As previously mentioned above, Bali as a world wide tourist destination is dominated by ceramic products from China and Vietnam that are considered to threaten the local ceramic market. At the national level, the similar thing was also conveyed by the Association of Indonesian Ceramic Industries (Asaki) Achmad Widjaya in 2012 on the website of the Ministry of Industry of the Republic of Indonesia. Widjaya stated that the products from China really become a threat to the domestic industry including the ceramics industry and they have dominated Indonesia's domestic market. It is in line with the statement from Abdul Basyir Gozali, a ceramics businessman in the area of Jalan Gatot Subroto Timur Denpasar, who explained on the online media of Bisnis Bali that the entry of imported ceramic products from China and Vietnam were considered to threaten the local ceramic market. It is because the imported products are relatively competitive with local products and their motives are more varied (Bisnis Bali, 2013, accessed in February 25, 2017). In addition, Bali has now become the center of marketing of various pottery types from various regions in Indonesia, for example from Yogyakarta, Jepara, and Lombok (Mudra, 2016) and become the marketing center of pottery products in Serang Banten West Java that have been produced in Bali (Sunarini, 2016). There are no ceramics business centers in Bali that feature the puppet motives as the ornaments in its production. A reason that often comes out from artisans is that they produce the product based on the market needs. If the market does not need such products, they do not produce it.
The creation of ceramic artwork with Balinese puppet style is one of the answers to manysolutions that can be offered to create the ceramics with Indonesian character. Besides, each region in Indonesia has a basic form of ceramic which becomes the typical characteristic of its regionality, among them has the similarities. The shape of this region's ceramics can be seen from the basic forms of traditional ceramics from each region, for example, the ceramic barrel from Lombok has a rather thick and round shape, while pottery pots from Java have a rather think and tall shape, and Bali has a barrel with a straight wall and enlarged to the top. This can be seen as a cultural capital as the effort to develop Indonesian ceramic characters.

\section{LITERATURE REVIEWS}

Based on the literature that has been explored thoroughly, it was found that some creations of ceramic art showcase various natural objects as an idea of its creation. Thoseartworks also become the inspiration for the creation of this ceramic artwork as it will be further discussed. The creation of ceramic artwork entitled "Rose Flowers as a Source of Ideas for the Creation of Ceramic Artworks" by Riska Tafrihatul Qulub from the Fine Arts Education Department, Language and Arts Faculty, Surabaya State University was published in the Journal of Fine Arts Education, Volume 05 Number 01 of 2017, 102- 109. The expression of roses in this work is an expression of the creator's feelingdue to herpast aesthetic experience. The creation of the artworks used slab and pinch techniques which produces 7 works with glaze finishing.

The next finding is the creation entitled "Butterfly as a Source of Inspiration for the Creation of Ceramics Works in Spa Room Equipment" by Ni Putu Yuda Jayanthi. In this work, it is explained that the creation of ceramic works was aimed at offering new innovations for the equipment in SPA room. In the embodiment process, the shape of a butterfly has been processed in sucha way by utilizing a soil medium of stoneware and glaze finishing (Jayanthi, 2013).

Another creation isa work entitled "Honey Bees as the Basic Idea for the Creation of Vase Ceramic Works" by Dandi Hilmi Zuhdi. This vase works to visualize the shape of insects based on the anatomy of body parts, color, and class. The techniques to create the artworks were pour printing, massage, spinning, slab and rotating with dying and coloring techniques using the brush. The main material of this ceramic vase is both solid and liquid Sukabumi clay. The work produced 12 ceramic vases with 2 twin ceramic vases. This ceramic vase is functioned as a place to put flowers and plants either replica or original (Zuhdi, 2016). From the above-mentioned ceramic art creations, we argue that the creation of ceramic art with the theme of puppets is very important because it features local culture with aesthetic and ethical values that can be modeled. 


\section{METHODOLOGY}

The creation of ceramic artwork was carried out through several stages based on the stages of artwork creation proposed by Gustami (2007: 329) consisting of exploration, improvisation (experiment) and embodiment. In the exploration stage, the data collection was done using the technique of observation, interview, and documentation. The data sources (research subjects) was conducted using the purposive sampling approach in which the data sources were intentionally based on the classifications of the required samples as well as snowball sampling. The examples were determining the work partners in the embodiment, ceramic theory experts, puppet stories experts, and painting experts of Balinese puppet style. The data sources selection was carried out carefully based on the scientific research principles to ensure the success of this creation.

In the improvisation stage, the design creation was done based on the result of exploration. The design creation was carried out by the researcher team assisted by the students to transform the manual design into the design of computer program such as Coreldraw. In the process of design making, the discussions were done by the research. The image design that has been created then were selected through Focus Group Discussion (FGD). FGD was carried out to get the suggestions from the participants to improve the design and to select the design that will be made. Furthermore, in the embodiment stage, the selected design was transformed into the ceramic artwork until the artwork was ready to be displayed. The embodiment of ceramic artwork design with the Balinese puppet style ornaments for the under glass ornament consisted of the embodiment and glaze burning. Mean while, the application of decoration on glass consisted of embodiment, biscuit burning, glaze burning, color ornaments application, and color burning.

The creation of ceramic artwork involved two partners, namely Tri Surya Ceramic Business and Balai Teknologi Industri Kreatif Keramik (BTIKK) Bali as previously mentioned above. The involvement of those partners was aimed at having the partners produce and publish the ceramic artwork that is created. If there are the demands from the prospective customers, those two partners can serve the prospective customers without involving the researcher team. This research was aimed at developing the partners' artworks in terms of design innovation with its own cultural characteristics. It is not like the foreign artwork that has been being produced so far. The creation of ceramic art can be categorized as applied research supported by qualitative data. Thus, this research used the qualitative method.

\section{RESULTS OF ANALYSIS}

The creation of ceramic artwork with the motives of Balinese puppet style as the ornament was carried out from
April to July 2018. This research was funded by the Ministry of Research Technology and Higher Education 2018 for the research grant of Research Creation and Display of Art (P3S). The process of ceramic artwork embodiment as the media to apply the ornament was done by rotary technique decorated by painting technique. The objects of the puppet chosen as the ornament were the roles of the puppets in one segment of the short stories. It was expected to represent the message of tolerance. The message of tolerance represented by this artwork is expected to be the guideline for the society in their daily life in order to avoid the tolerance disruption in Indonesia. The people of Indonesia consist of various identities which are spread across many areas in which each area has a unique culture. Identities diversity can be viewed as the wealth as well as the threat to the harmony of community life in the form of tolerance. A piece of puppet story in the form of decoration as what was done in this research is expected to convey the message of appreciation for any difference as it does not feature one identity too much, so the peace can emerge in the community life.

This ceramic art product is layered with transparent and white glaze. The creation of this work is seen from the two decoration techniques that were used, namely the underglaze product and the above glaze product. The products that apply underglaze decorations used the transparent glaze, while the products that apply above glaze decorations used white glaze. The size of the work that has been made varied from a small size of $20 \times 28 \mathrm{~cm}$ to the largest size $45 \times 70 \mathrm{~cm}$. Most of the works created can be used as a decorator as well as Balinese or Indonesian special souvenirs. As a decorator, the placement of the artwork can be flexible since it does not require the artwork to be placed in a certain room, but it can be adjusted to the room which is provided. As a souvenir, the artworkhasits own distinctive values that differs from other ceramic works since its form is inspired by Indonesian traditional culture. The puppet characters that are displayed will be the characteristic of this ceramic work. The applied function of this artwork is to be the place of holy water. In Bali, the place of holy water is called as sangku and is used during religious ceremonies.

The creation of this ceramic artwork adopts the basic form of traditional ceramic forms which are also called as pottery coming from various regions in Indonesia, such as from Lombok, Bali, and Yogyakarta. The pottery from Lombok and Yogyakarta has the basic shape of a barrel or vase which are sold in the Kapal Village of Badung Regency, Bali (Mudra, 2016). Mean while, the pottery from Bali has the basic form of sangku (holy water place). Each design that is created was made in several size variations. There were 1-2 works available in bigger size, while the smaller size was available in 1-3 works. The purpose of creating various sizeswas to provide more choices to the community that possibly become the prospective users. 

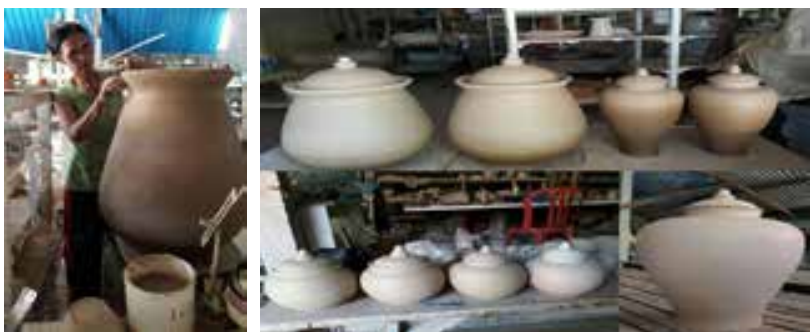

Figure 1. The formation process (above) and severalartworks in the drying process (below) in Tri Surya Keramik. Source:

Documentation of I Wayan Mudra 2018

These basic forms are not fully innovated in order to keep displaying the Indonesian character of those ceramic artworks which were based on local ceramic artworks. The quality of the work and the puppet ornaments becamethe benchmarkin making this work to be the Indonesian ceramics works that can be accepted by the community.

The partners of this creation, Tri Surya Ceramics and Balai Teknologi Industri Kreatif Keramik (BTIKK) Bali, found the difficulty during the process of forming ceramic bodies in which the designs were categorized as the large size. According to its founder, the problem occurred in the type of soil that is less supportive for high pottery bodies. The formation was generally carried out in relatively small size ceramic bodies according to the demands of the market, so there were no obstacles found in the production. The researchers viewed the phenomenon as the normal thing since the two partners have not formed the ceramic bodies in relatively large size as shown in the following figure.

The work partners did the formation for the first time, then they were challenged to further do the formation. The researchers attempted to keep giving the explanation that the formation can be done. The only problem existed was the formation that had never yet been done. The craftsmen understand that there are many craftsmen outside Bali that are able to form the ceramics in the larger size using slightly different techniques than those generally done. Due to the researchers' motivation, the partners believed that they could do this formation. The partners have high confidence and enthusiasm in this formation process. Therefore, the obstacles can be overcome, the works can be created, and it becomesthe pride of the researchers and partners. However, there were some broken works in the process of biscuits burning, especially the relatively large-works. The following is a description of each ceramic craft product that has been created.

\section{Sangku}

This work was inspired by traditional Balinese ceramic pottery products called as sangku. Sangku is functioned as a place of holy water used by Hindus in Bali to perform sacred ceremonies or prayers. This ceramic artwork was made with rotary technique which varies in size and
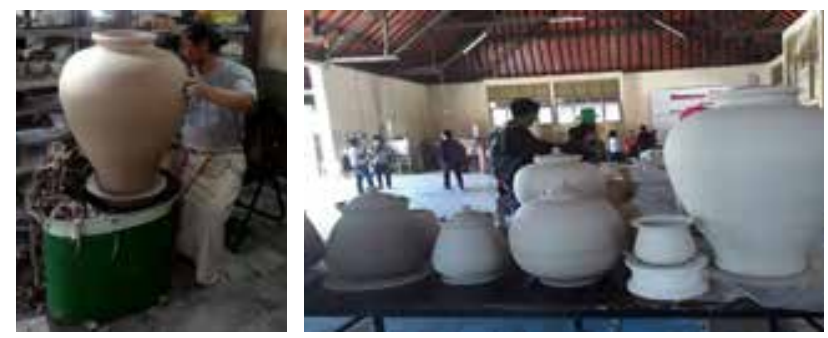

Figure 2. The formation process (above) and several works in the drying process (below) at the Center of Bali Ceramic Creative Industry Technology (BTIKK) Bali. Documentation of I Wayan Mudra 2018

was decorated with Balinese on glass puppet motifs. It was burned at high temperatures and createdby the ceramic business partner, they were Tri Surya Keramik in Br Belulang, Kapal, Mengwi, I Made Rai Sandiana. Below are several sangku products with their variations.

Figure 3 shows some of the ceramic artworks inspired by the shape of sangku that has been equipped with Balinese puppet style ornaments. Theseproducts consisted of various size variants ranging from right to left. Each was $60 \mathrm{~cm} \times 23 \mathrm{~cm}, 48 \mathrm{~cm} \times 33$ and $35 \mathrm{~cm} \times 23 \mathrm{~cm}$ in size. This ceramic artwork can be used as a disposable object and also for decorative objects. The application of puppetornaments was carried out on glass using special ceramics colors. The burning process of ceramic artworks was through three stages, namely biscuits burning, glaze burning, and colors burning.

Each ceramic artwork in Figure 3 above is put the ornaments of two puppet characters namely Dewi Sita and Hanuman which were taken from the short part of the meeting stories of Hanuman, Rama, and Laksamana's. The objects of Dewi Sita and Anoman were painted on the front and back of the work. The use of those 2 figures as the ornaments in this work was based on the consideration to make the puppet characters look bigger so that they can look more attractive. It was because the surface of the ceramic area was narrow and the surface was convex.

The short part of the meeting stories of Hanuman, Rama, and Laksamana was started from Dewi Sita who was kidnapped by Rahwana in the Kiskinda kingdom. There was a war to wrest the power between the siblings, they were Sugriwa and Subali. Hanuman who was anxious about the incident seek help and met Rama and Laksmana. Hanuman told the story of what happened to the Kiskenda kingdom. Finally, Rama Laksmanawas compassionately willing to help Hanuman. On the other hand, Hanuman and his friends were ready to help Rama Laksmana who was kidnapped by Rahwana.

The meaning of tolerance that can be conveyed by this short part of the story is the prohibition to fight among others in obtaining the power. In a democratic country, 

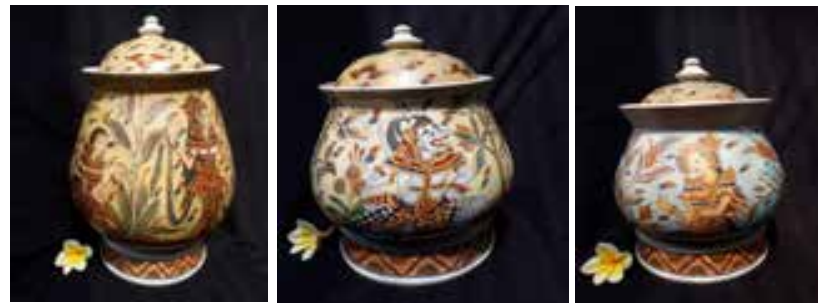

Figure 3. Several sangku variations with Balinese puppet style ornament Source: Documentation of I Wayan Mudra 2018.
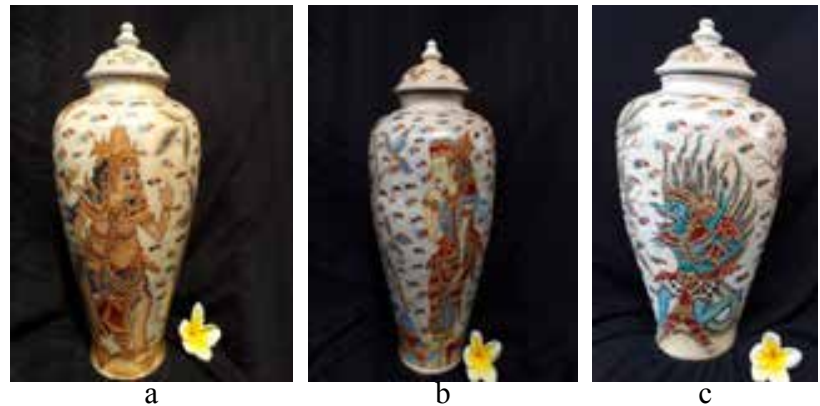

Figure 4. The third variant of the vase, the figure a and be is the same work, while figure $\mathrm{c}$ has the same ornament as Jetayu. Source: Documentation of I Wayan Mudra 2018. anyone can be in power, but it must be obtained based on the applicable law. Everyone has the same rights and obligations above the law in obtaining power. Obeying the law means obeying tolerance, respecting others' rightsand obligations, and not imposing themselves. Thus, the peaceful society can be realized.

\section{Vase}

This ceramic artwork in the form of a vase was inspired by a vase-shaped pottery product from Java which was marketed in Bali, some of which come from Kasongan, Plered, and Malang. The form of vases from Java that are marketed in Bali is generally vertical since the height is greater than the size of the diameter. Besides, the diameter size of the top section of the Javanese pottery vase was rather similar to the diameter size of the bottompart to Lombok pottery vase. The following are several works of the vase in this creation.

Figure 4 shows the first works (surface $\mathrm{a}$ and $\mathrm{b}$ are high) and the second work (surface $b$ ) that have the same size $45 \mathrm{~cm} \times 25$ and were made by rotary technique. This work has the motif of Balinese puppet style figures such as Rahwana, Dewi Sita, and Jatayu. These ornamental motives were taken from the short part of Ramayana story. The figures of Rahwana and Sita were used as ornaments on both surfaces, while other works applied Jatayu and Sita on both sides. The short part of this story tells that Jatayu got a message from his ancestors. When he heard the crying to ask for help in the air, he should give his hand without thinking about who to help and what situation occurred at that time.Then, Jatayu immediately flew to find the source of the cry and met Dewi Sita who was being rushed by

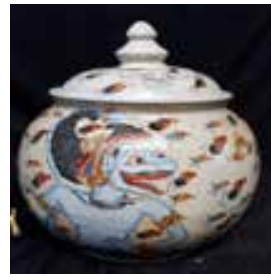

a

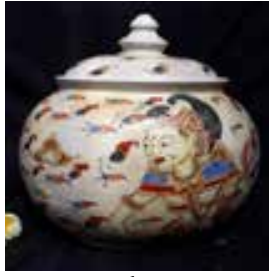

b

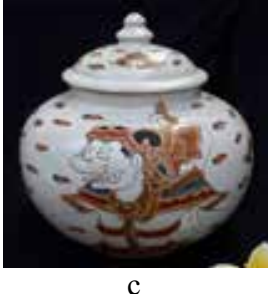

Figure 5. Round vase with three variants of ornaments. Source: Documentation of I Wayan Mudra 2018.

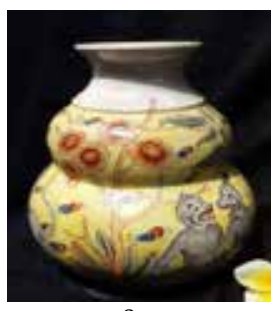

a

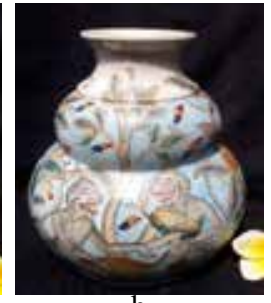

b

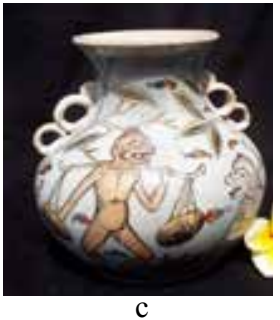

Figure 6. Bottle vase with its various shapes and ornaments. Source: Documentation of I Wayan Mudra 2018.

Rahwana. A terrifying fight happened to take Dewi Sita away. This battle was won by Rahwana that was done by cutting Jatayu's wings until he finally fell to the ground. The meaning of tolerance that can be explained by the occurrence of the puppet story is to help anyone without seeing the identity of the person being helped. The help must be done sincerely as it is an obligation that should be done by everyone. It has been done by Jatayu who was mandated by his ancestors. This story gives the moral lesson that helping others should be done sincerely. We should not see someone's identity from his or her religion, beliefs, origins of birth, wealth, and others. The main thing is by helping the otherswho really need help. The message of tolerance contained in the story above is very deep and good to be used as a guide in living the community life in Indonesia. Therefore, peaceful circumstance is created in the plural community atmosphere. Indonesian people in some places arefrequentlylack of concern for others and still prioritizing the individualism in society. It is reflected in electronic media showing that often display various violence and bombings that cause many victims. Moreover, it looks like there is no regret from the perpetrators.

\section{Round Vase}

The round vase artwork is inspired by the shape of the pottery vase that is widely marketed in Bali, especially in the areas along Kapal Village Mengwi Badung. The shape that is created from the top part was done by removing the bottom part like a vase in common. This vase artwork was made of $26 \mathrm{~cm} \times 23 \mathrm{~cm}$ in size and is very suitable to be used as a souvenir due to its relatively small size, as shown in the following picture.

This work also applied Balinese puppet style ornaments using painting techniques. The round vase artwork shows 
that various ornaments were applied. Each artwork appears in the same shape and size applying different ornaments. It was also implemented to other types of products. The figura of $6 \mathrm{a}$ above applied puppet ornaments of Hanuman characters in the front part and Rama on the other side. The artwork 5b applied the characters of Rama and Laksman, while the figure $5 \mathrm{c}$ applied the character of Sugriwa-Subali. The puppet character depicted in this artwork is the top part of the character. It was aimed at obtain the bigger puppet picture to make it more clearly seen by the appreciator. By having that appearance, it is expected that this artwork looks more attractive since the surface area of the body is convex and narrow. This work is symmetrical and simple in which the uniqueness is also expected to emerge from the visualization of the artwork ornament. As a souvenir featuring Balinese or Indonesian identity, this round vase can function as a room decorating object as well as a container for something, for example as a place of jewelry. As the size is relatively small, it is very easy to carry the things both in short and long distance trip. The researchers believe that these types of vase are rarely found even no one has made them; therefore, this artwork is considered to be a limited work with its own peculiarities.

\section{Bottle Vase}

This ceramic artwork is named as bottle vase because it looks like a bottle inspired by various types of flower vases marketed in Bali. This artwork has a simple and symmetrical shape. It is varied by its shapes and ornaments as shown in the following figure.

Figure 6 above shows the bottle vase $a$ and $b$ are in the same shape and size is $27 \mathrm{~cm}$ high and the diameter is $15 \mathrm{~cm}$. This artwork only displays various basic colors of the ceramic, namely yellow and white. The shape of the body consists of a composition of two spheres shrinking upwards and accompanied by a wide mouth. The bottle $\mathrm{c}$ vase is $25 \mathrm{~cm}$ high and the diameter is $17 \mathrm{~cm}$, the shape is simple as the bottle a and $b$. The difference is on the left and right sides which are given an additional circle shape that can be used as a handle. Ceramic artworks can be used as disposable objects such as the vase for both dry and wet flowers. Besides, this artwork can also function as a decorative object to decorate a room or closet. This bottle flower vase can also be used as a souvenir object featuring the Indonesian character for local and foreign tourists. Those three artworks were made using a rotary technique having an ornament with the same theme, such as that motive of several ape animals depicted as they carry the stones. This motive was inspired by Ramayana story when King Rama ordered his ape troops commanded by Hanuman as the ape commander to build the Situbanda Bridge connecting the land of Bharatawarsa with Lankapura aimed at facilitating the war. The ape troops built the Situbanda Bridge of pumice and sand. The results of this creation have produced ceramic artwork with Balinese puppet style ornaments. The creation of ceramic artworks is aimed at answering the problems presented in the introduction, namely to display the message of Indonesian characters, or in other words to create Indonesian ceramic art. Indonesian ceramic artwork means ceramic art that is capable to display Indonesian identity which distinguishes ceramic art from other countries. The researchers believe that the artworks produced in this creation are able to showcase Indonesian characteristics as these works feature Indonesian culture like puppet, especially Balinese puppet style. Puppet is one of the original Indonesian traditional arts that has been widely known by the public for a long time. It is stated by Brandes, G.A.J. Hazeu, Rentse, Kats and Kruyt stating that the puppet art is originated from Indonesia. Moreover, Hazeu states that puppet art is originated from Java (Darmoko at http://staff. ui.ac.id, accessed on July 29, 2018). Each region in Indonesia has different visual characters of puppet. Puppet art is a cultural capital that is owned and can be developed by Indonesia to improve the identity of Indonesian people. Bourdieu's cultural capital is basically in the form of belief in value about everything that is considered right and always followed by efforts to be actualized in social life (Sumarno, 2013: 70). Cultural capital in the form of puppets has been applied to ceramics works in ceramic art media as an effort to display the identity of works that showcase Indonesian characters.

The achievement of the final results is expected to be in accordance with the objectives, namely ceramic artwork featuring Indonesian characters or ceramic art that is able to showcase the uniqueness of Indonesia to the world. This assessment was determined by the community as an appreciator after appreciating the publication of works through exhibitions, writing articles in journals and other media. The researchers believe that this goal can be achieved, though it will take time for the publication process. The researchers' observations were through the FGD activities at the Art Crafts Study Program of Fine Arts and Design Faculty of ISI Denpasar in June 2018 and limited online publications, these works are quite popular in the public. Variables showing that case can be viewed when some people who have expressed their interest in having the artwork by buying the product. Further people's appreciation for this ceramic artwork will be seen in the upcoming exhibition. By inserting local cultural content in a work, an appreciator will not only be directed to the understanding about the culture but also the understanding about the form that only appears on the surface. A product is not only perceived through visual forms appeared on the surface, but also can be perceived from its cultural elements, for example, certain traditions that can be known, certain ways of thinking and so on (Vihma, 1990: 116).

These created ceramic artworks were more dominant in ornamental function than their practical functions as a place or container. It is due to the application of Balinese puppet ornaments in this artwork which is more dominant in feature the product as decorative items with its beauty 
value that can beautify the room. Thus, the practical functions of the work are often neglected by the appreciators or the users.

The application of Balinese puppet as an ornament in the creation of ceramic art also increases the selling value of the product to be higher than other types of ornaments. The cost of producing ceramic art is also higher than that using ceramic dye paints that do not require combustion. This puppet ornament on ceramic art uses special colors of ceramics and must be burned at a certain temperature to get the long-lasting color like the glaze. Thus, the burning of ceramic art in the creation was done in three stages, namely biscuits burning, glaze burning and colors burning.

\section{DISCUSSION}

The results of this creation have produced ceramic artwork with Balinese puppet style ornaments. The creation of ceramic artworks is aimed at answering the problems presented in the introduction, namely to display the message of Indonesian characters, in other words, to create Indonesian ceramic art. Indonesian typical ceramic artwork is the ceramic art which is capable to display the Indonesian identity which distinguishes the artwork from other countries. The researchers believe that the works produced in this creation are able to showcase Indonesian characteristics. It is because these works feature Indonesian culture capital like puppet especially Balinese puppet style. Puppet is one of the original Indonesian traditional arts that has been widely known by the public for a long time. It is stated by Brandes, G.A.J. Hazeu, Rentse, Kats, and Kruyt that the original puppet art is originated from Indonesia; moreover, Hazeu states that puppet art is originated from Java (Darmoko at http://staff.ui.ac.id, accessed onJuly 29, 2018). Each region in Indonesia has different visual characters of the puppet. Puppet art is one of Indonesia's culture that can be developed in featuring Indonesian identity. Bourdieu's cultural capital is basically in the form of a belief in values about anything that is considered right and is always followed to be actualized in social life (Sumarno, 2013: 70). The cultural capital in the form of puppethas been applied to ceramic artworks on ceramic art media to display the identity of artworks having Indonesian characters.

The achievement of the final result is expected to be in line with the objectives, to showcase the uniqueness of Indonesia in the worldthrough ceramic art with Indonesian character or ceramic art. This assessment is determined by the community as an appreciator after appreciating the publication of works through exhibitions, writing articles in journals, and other media. The researchers believe that this goal can be achieved, even though it will take time for the publication process. The researchers'observations were through the FGD activities at the Art Crafts Study Program of Fine Arts and Design Faculty of ISI Denpasar in June 2018 and limited online publications, these works are quite popular in the public.Variables showing that case can be viewed whensome people who have expressed their interest in having the artwork by buying the product. Further people's appreciation for this ceramic artwork will be seen in the upcoming exhibition. By inserting local cultural content in a work, an appreciator will not only be directed to the understanding about the culture but also the understanding about the form that only appears on the surface. A product is not only perceived through visual forms appeared on the surface, but also can be perceived from its cultural elements, for example, certain traditions that can be known, certain ways of thinking and so on (Vihma, 1990: 116). These created ceramic artworks were more dominant in ornamental function than their practical functions as a place or container. It is due to the application of Balinese puppet ornaments in this artwork which is more dominant in feature the product as decorative items with its beauty value that can beautify the room. Thus, the practical functions of the work are often neglected by the appreciators or the users.

The application of Balinese puppet as an ornament in the creation of ceramic art also increases the selling value of the product to be higher than other types of ornaments. The cost of producing ceramic art is also higher than that using ceramic dye paints that do not require combustion. This puppet ornament on ceramic art uses special colors of ceramics and must be burned at a certain temperature to get the long-lasting color like the glaze. Thus, the burning of ceramic art in the creation was done in three stages, namely biscuits burning, glaze burning and colors burning.

\section{CONCLUSION}

The creation of this ceramic artwork produces artwork having the simple form and displaying Indonesian traditional art culture, namely the Balinese puppet style. The simple form which isdisplay is intended to make the people easily recognize these Indonesian ceramics. This creation applies Balinese puppet style motifs as the ornaments to have the ceramic works with Indonesian characters. Puppet is one of Indonesia's traditional arts and cultures that still exists until the present in the Java and Bali Island. Each visualization of Indonesian puppet has its differences that distinguish them from other regions. Puppet art has been well-known and popular in Indonesia and even the world; therefore, it is quite easy to build Indonesian characters through this puppet art.

The achievement of this ceramic artwork with the Indonesian character is determined by the appraisement of the people as the appreciators of the work. The embodiment of the work was carried out with a rotary technique, while the ornaments were applied using painting technique. Several works that were successfully created were sangku, jars and vases. Each work is made in several size variants, orna- 
ment, motifs, and coloring. The embodiment of this work involves two partners namely Tri Surya Keramik Business and Bali Creative Industrial Technology Center (BTIKK). The researchers view that the works of ceramic art creation need to be further maximized to obtain optimal results.

\section{ACKNOWLEDGMENT}

The researcher would like to thank Kemenristekdikti for funding the creation of this work in the form of research grants. Moreover, the researchers also thank the two partners namely Tri Surya Keramik and Balai Teknologi Industri Kreatif Keramik (BTIKK) Bali who have helped us in the realization of the researchers' design. Gratitude is also conveyed to lecturers of the Arts Craft Department of the Vusial Art and Design Faculty in Indonesian Institute of the Arts Denpasar.

\section{REFERENCES}

Barker, Chris. (2004). Cultural Studies: Teori \& Praktik. (Nurhadi, Pentj). Yogyakarta: Kreasi Wacana.

"Beberapa pendapat asal-usul wayang di Indonesia." Darmoko. http://staff.ui.ac.id. 28 Juli 2018.

"Gallery Twenty Eight: Using Symbols and Metaphots to Express Meaning by Phil Douglis." PBase.Web.11 Dec. 2015

Gustami, SP. (2007). Butir-Butir Mutiara Estetika. Yogyakarta: Prasida.

Jayanthi, Ni Putu Yuda. (2013). Kupu-Kupu Sebagai Sumber Inspirasi Penciptaan Karya Keramik Pada Peralatan Ruang Spa. Tugas Akhir (TA) Jurusan Kriya Seni Fakultas Seni Rupa dan Desain Institut Seni Indonesia Denpasar.

“Kapolri: Tantangan Era Ini Menjaga Kebhinekaan”. Raw. http://jabar.tribunnews.com. 24 Januari 2016.

"Keramik Cina dan Vietnam Ancam Produk Lokal". https://www.bisnisbali.com. 25 February 2017.

Mudra, I Wayan. (2016). "Marginalisasi Gerabah Hias Bali di Desa Kapal Badung pada Era Globalisasi" (disertasi). Denpasar: Universitas Udayana.

Nugraha, Adhi. (1999). Kriya Indonesia, sebuah wilayah sumber inspirasi tak terbatas. Makalah Konprensi Kriya dan Rekayasa di ITB Bandung, 26 November 1999.

Qulub, Riska Tafrihatul. (2017). Bunga Mawar Sebagai Sumber Ide Penciptaan Karya Keramik. Jurnal Pendidikan Seni Rupa 05 (01): 102-109.
Rhodes, D. (1971), Clay and Glazes for the Potter, Philadelphia New York London. Chilton Book Company.

San. (2017). Perajin Gerbah di Desa Pejaten Makin Langka. Media Bali Post, Kamis 25 Januari 5 Januari 2017, halaman 20 .

Sunarini, Ni Made dan I Wayan Mudra. (2016). "Fenomena Reproduksi Gerabah Serang Banten di Bali" (Laporan Penelitian Fundamental). Denpasar: Institut Seni Indonesia Denpasar.

"Symbolism Movement, Artists and Major Works." The Art Story. Web. 11 Dec. 2015.

"Sejarah Asal-usul Wayang." Samin, Cah. http://caritawayang.blogspot.co.id/2015/04. 12 May 2018.

"Serbuan Keramik China Resahkan Keramik Lokal" http://www.kemenperin.go.id. Diakses 25 Juli 2018.

Sumarno, dkk, "Orientasi Modal Sosial dan Modal Kultural di Fakultas Ilmu Pendidikan U.N.Y.", Jurnal Ilmu Pendidikan, Vol. 6 No. 2 (September, 2013), 70.

Tabrani, Primadi. (2006). Kreativitas \& Humanitas. Yogyakarta. JALASUTRA.

Vihma, Susann. (1990). "Bentuk Produk Sebuah Pendekatan Semiotika" dalam Susann Vihma dan Seppo Vakeva (Eds.) "Semiotika Visual dan Semantika Produk, Pengantar Teori dan Praktek Penerapn Semiotika dalam Desain”. (Ikramullah Mahyuddin, Penerj.). Yogyakarta: Jalasutra (hal. 116).

Zuhdi, Dandi Hilmi. (2016). Lebah Madu Sebagai Ide Dasar Penciptaan Karya Keramik Jenis Vas. Tugas Akhir (TA) Program Studi Pendidikan Seni Kerajinan Fakultas Bahasa dan Seni Universitas Negeri Yogyakarta. 